Article

\title{
Sustainable Education: Using Social Networks in Education for Change
}

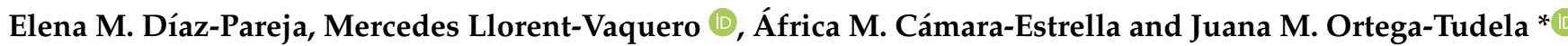

Citation: Díaz-Pareja, E.M.;

Llorent-Vaquero, M.; Cámara-Estrella, Á.M.; Ortega-Tudela, J.M. Sustainable Education: Using Social Networks in Education for Change. Sustainability 2021, 13, 10368. https://doi.org/ $10.3390 /$ su131810368

Academic Editor: José Carmelo Adsuar Sala

Received: 19 August 2021

Accepted: 14 September 2021

Published: 16 September 2021

Publisher's Note: MDPI stays neutral with regard to jurisdictional claims in published maps and institutional affiliations.

Copyright: (c) 2021 by the authors. Licensee MDPI, Basel, Switzerland. This article is an open access article distributed under the terms and conditions of the Creative Commons Attribution (CC BY) license (https:/ / creativecommons.org/licenses/by/ $4.0 /)$.
Department of Pedagogy, University of Jaén, 23071 Jaén, Spain; emdiaz@ujaen.es (E.M.D.-P.); mllorent@ujaen.es (M.L.-V.); acamara@ujaen.es (Á.M.C.-E.)

* Correspondence: jmortega@ujaen.es

\begin{abstract}
Creating societies of the future goes hand in hand with promoting sustainable education and, therefore, universities must train educators who, through their own professional development, put into practice methodologies that are active, participative, and focused on the overall development of their students. The use of methodologies like Design Thinking and the use of social networks generate learning dynamics that bring into play key competences in the development of dedicated future educators. In this study, 156 students from Education degrees at the University of Jaen analyze how the use of these methodologies supports the learning process in dimensions such as creativity, motivation, communication, and involvement in learning, among others. The results shows that all dimensions correlate positively, and that the benefits derived from the use of these methodologies are perceived by students as greater than the effort required to put them into practice.
\end{abstract}

Keywords: teachers training; social networks; design thinking; sustainable education

\section{Introduction}

We are living in tumultuous times, at both the social and the educational levels, which have only been exacerbated by the situation relating to COVID-19 [1-3]. The circumstances are demanding a fundamental change in universities, both in their vision of the professionals to be trained and in the didactic methodologies used to do so. It must not be forgotten that higher education institutions have a clear social commitment [4]; that is to say, they must be connected to their communities, supporting the transformation and improvement of social reality. If we intend to create an innovative, inclusive, and responsible society, then the university must train future professionals to be more just, more committed to their profession, more involved in the society around them, and more inclined to facilitate social transformations, including in their immediate environment.

For [5], the neglect within higher education of aspects of learning such as civic commitment, across all of Europe, has been partly responsible for the low participation and interest of young people in issues relating to social problems, citizenship, or civic awareness [6]. However, some research [7-9] shows that participatory methodologies like Design Thinking (DT) help to develop these dimensions and promote new ways of educating that mean we train professionals committed to change, while developing social responsibility within them.

To facilitate this process, like [10], we believe that it is necessary to take advantage of and make use of the media, the languages, and the environments used by our students in the present day; that is to say, social networks. Therefore, we propose establishing a connection between active and participatory methodologies (DT) and certain technologies, specifically social networks, integrating them within the university with the purpose of transforming the teaching-learning process. 


\section{New Forms of Teaching and Learning: Design Thinking}

Let us discuss different didactic proposals that facilitate learning and make it much more active for students. The key competences, as they have been labelled, that we must develop in our students require a practical implementation in line with the present demands of a changing society [11], and DT can be postulated as a well-adapted strategy for developing constructivist learning opportunities. In constructivism, learning is a process of individually self-organising knowledge. In this framework, learning is identified as a multifaceted process of structured interaction between students and their natural and social environment [12]. Moreover, learning is a process requiring constant adaptation to situations, and teachers should facilitate this adaptation by designing educational experiences.

Design Thinking could be a constructivist learning design because of its qualities to develop certain skills that can give rise to constructive ways of learning: motivation for exploration, openness to new ideas, creative thinking, and other metacognitive competences [12].

Design Thinking is a person-centered innovation methodology [13], starting from the creative and innovative capacity that we all have for resolving problems, but that we often forget due to conventionalisms [14]. According to these authors, DT is based on skills such as intuition, recognition of rules and patterns, the construction of ideas with emotional components, functionality, and expression in communication media beyond words and symbols. This method focuses on the design process, more than the final product, and integrates knowledge from various areas such as the social sciences, business, design, and engineering. Fundamentally, DT seeks to $[15,16]$ :

Understand in depth; study by way of the acquisition of basic information about users or about a problem or situation.

- Observe; achieve empathy with users and their needs.

- Define; design a solution or product for the specific user at hand.

- Devise; produce all possible ideas for said product.

- Develop prototypes; build prototypes only according to the most satisfactory ideas.

- Test; trial the different prototypes to verify their effectiveness with users.

Given that DT takes into account the real needs of people at the individual and social levels, as well as the consequences of solutions or products for the environment [9], we can speak of the social responsibility of both the design and the designer-of rendering the whole process more sustainable [7-9]. In addition, DT allows students to learn more effectively: by contextualizing the challenges that they have to face, and by bringing these closer to their social reality, it fosters students' intentions to transform and improve said reality [17]. Ultimately, students' commitment and their participation are promoted, and they become protagonists in a collaborative process of creating and designing creative solutions [11]. These benefits of DT in education refer to its character, which enables students to work successfully in work groups [18]. In their research, [18] proved that once succeeded in the process, the teacher gets positive feedback and the development of students' social competences can be assessed.

DT promotes a positive relationship between teachers and students [19], and confirms the fostering of students' metacognitive competences such as innovation, problem solving, creativity, collaboration, and communication skills [19-23].

This process of success leads to the motivation of both students and teachers to develop further constructivist learning environments [18]. According to this, [19,22,24-26] further argued that design thinking - as a constructivist learning strategy—allows the student to be motivated for exploration and problem solving, open to ideas, and to experience increased innovation and creativity. Design Thinking is effective in fostering 21st century learning through its application in complex interdisciplinary projects in a holistic constructivist manner [18]. 


\section{Didactic Use of Social Networks}

A further potentiality of active methodologies, and the convenience of their use in the new educational context, derives from the ease with which they support the incorporation of ICT, specifically social networks, into the educational field [27]. Moreover, it is necessary to bear in mind that this incorporation must go together with profound changes in the whole system, including methods, organization, and assessment. A social network can be defined as a structure within society wherein individuals relate to each other, establishing distinct types of relationships, such as financial exchange, friendship, emotional relationships, or those based on information, among other types [28]. As such, we are speaking about an online communication space, in which users are in contact and share content regardless of time, space, or location.

Ref. [29] identify three categories of social media:

- Online communities that put friends and acquaintances in contact with the purpose of exchanging experiences, ideas, or resources. The best known online communities serving this purpose are Facebook, MySpace, Twitter, and Instagram.

- Sites that provide for the sharing and organization of content, such as Delicious, Digg, Flickr, or YouTube.

- The final category is composed of websites for creating and editing content, of which the best known are Blogger, Google Docs, Wikipedia, and WordPress.

Social networks can be of great potential in the training of our students, as they help to create collaborative learning environments [30,31], have a more flexible character in terms of space and time, and offer new contexts for working and relating to each other. With the use of these tools, the student can regain the leading role in their own learning [32], which is why they are becoming an essential mechanism for teaching. In addition, as authors state, the use of social networks can be beneficial not only in this formative stage, but also in the professional development of our students, given that these networks will be very much present in their working environment [33].

On the other hand, studies on mobile communication show that the use of social networks and of mobile telephones, especially for the exchange of information, are an effective means for young people to participate in civic life [34]. Starting from the idea that knowledge is created in collaboration and interaction with others, social media responds to the need to participate in a social context or community to generate said learning $[31,35,36]$. Social networks foster participative digital cultures through collaborative learning and the acquisition of new skills.

More than ever, the personal disconnect of the pandemic - which has resulted in a reduction of in-person teaching in university classrooms, in many cases by as much as $60 \%$ - has obliged us to seek new forms of motivation, such that we need to rethink the educational potential of some tools in order to make the most of them and to establish new modes of communication [37]. Hence, the use of social networks, in particular Instagram, might help us to perform monitoring work, facilitating contact with our students, and enhancing their participation. Instagram has become highly popular among young people as a social network in which users can edit and share photos and videos [38], add locations and tag other users, send messages, and interact on other users' posts. Turning its use to the university classroom, it is possible for us to get closer to the world of our students, beginning from the language that they use in their spare time, while setting rules that make it into a pedagogical tool. We defend the view that using technology without a clear purpose, and without modifying the teaching method, leads us nowhere [39]. In a similar vein, research carried out by [40] (p.31) concludes that: "... without guidance and instruction teachers will often use technology to 'do old things in new ways' rather than transform and improve approaches to teaching and learning".

To complement the benefits of participatory methodologies that have been demonstrated in university [41], we intend to add the expected benefits of using language and environments that appeal to young people, which may allow significant improvements in the teaching and learning process. 


\section{Design and Methodology}

The principal objective of this study is to analyze to what extent the use of social networks and DT methodology influenced the learning processes of university students undertaking Education degrees. On the basis of this objective, a positivist methodology was employed, using a descriptive method and a survey design.

The study was carried out with 156 students from the following degrees at the University of Jaén: Master's in Primary Education $(\mathrm{N}=65)$, Master's in Early Childhood Education $(\mathrm{N}=61)$, and Social Education $(\mathrm{N}=30)$.

All students participated voluntarily, within the subjects of School Organization (second year of Primary Ed and Early Childhood Ed) and Socio-educational Projects in Childhood and Youth (fourth year of Social Ed), in the development of practices based on the use of Design Thinking methodology and on the use of social networks (specifically, Instagram) for the dissemination of the process and results.

Work teams of approximately 5 students were organized within each subject, such that, in the end, 19 (Primary Ed), 20 (Early Childhood Ed), and 12 (Social Ed) groups of students were established.

The process of developing these practices unfolded in two different phases. One of the first activities carried out with the students was the analysis of the needs of their social environment, which students were able to respond to using learning acquired in their subjects. Based on this analysis, three major challenges were noted: (1) art for all, centered on the development of workshops and audiovisual aids to promote understanding of different forms of art; (2) awareness of the social environment, by way of awareness raising campaigns on a range of issues, such as the environment and recycling, noise pollution, respect for common areas, consideration and prevention in respect of COVID-19 among children and young people, gambling in young people, conflict behaviors in young people, eating disorders, sex education, toxic relationships in adolescence, public understanding of children with ASD, etc.; and (3) inclusive and accessible communities, sharing knowledge and providing help to vulnerable people.

Subsequently, students had to plan microservices directed at solving the problems identified. These projects had to be designed in line with the core concepts proposed: art for all, positive citizenship practices, and inclusion. To carry out the projects, the DT methodology was proposed, with the aim of obtaining creative solutions to these problems. Thus, within the School Organization subject, work teams were tasked with providing solutions to deal with the above challenges through the development of technological tools that could be offered to the relevant target groups (educational videos and videogames for children, in the case of Early Childhood Ed and Primary Ed groups, that would address the proposed challenges). In the Socio-educational Projects subject, concerned with children and youth, the agreed task was the development of microprojects to boost awareness and sensitivity in relation to the above issues.

On the one hand, the work teams had to follow the following stages of Design Thinking for the creation of materials: understand the problem, empathize with the people targeted by the project, define the challenge, devise as many solutions as possible, construct or design resources that respond to the challenge, and test the resource to see if it meets the challenge for which it was created.

On the other hand, the Instagram social network was used to disseminate all the results obtained and to facilitate motivation, monitoring, and presentation of said results.

The projects were carried out over the course of a university semester. Once the practices were completed, an ad hoc questionnaire was administered to evaluate the development process of the projects, focused above all on the impact of the DT methodology and the use of the Instagram social network within them.

\subsection{Data Collection Instruments}

To collect data, we used an evaluation scale composed of 38 items, organized into nine dimensions, and designed specifically for the research study. The first dimension 
corresponded to identification data (gender, age, degree course, etc.) in addition to other items that would later help us to interpret the data on the basis of students' previous experiences with these techniques (if they were repeating their studies, if they had already used this methodology, etc.).

The eight remaining dimensions corresponded to the fundamental competencies developed:

- Motivation: Centered on the motivation to carry out the practices and on the level of motivation toward learning through new resources and technological applications.

- Involvement: To connect; to participate; to achieve learning objectives; to get involved in group work.

- Creativity: Seeking out sources of inspiration; seeking out a variety of answers; thinking differently; using a variety of resources.

- Communication: Within the class group; among group members; between groups and teacher; quantity; quality; fluency.

- Monitoring: Guidance; drive; feedback; Teacher's Guide; support.

- Dissemination: Publicizing results; promoting one's work; promoting one's group; public dissemination.

- Success: Motivation to succeed; feeling of a job well done; perception of joint achievement; perception of the usefulness of the work.

- Social involvement: Arousing interest in the service; encouraging participation in other social actions.

Each of the dimensions was operationalized in measurable items, which were duplicated so that the student was able to evaluate the extent to which Design Thinking and social networks had helped in the achievement of each item. Said items were answered on a Likert-type scale with six response options: $0=$ not at all; $1=$ very little; $2=$ a little; 3 = somewhat; $4=$ quite a lot; $5=$ a lot.

A reliability and validity analysis was carried out in order to determine the quality of the measuring instrument. The procedure used was expert judgement, by which an assessment of each item's quality and relevance was carried out by 5 expert judges. The analysis performed using Lawshe's Content Validity Ratio (CVR) revealed all items to have scored above $X=3.8$ for relevance. In addition, the analysis of the content validity index for the whole instrument found $(\mathrm{CVI}=0.966)$ [42]. Items were revised and modified according to suggestions on clarity provided by the experts. As regards the reliability of the instrument, it was determined using Cronbach's alpha coefficient, with a value of 0.988 obtained. The questionnaire was administered to the students electronically, using a Google form.

\subsection{Sample}

A total of 156 students responded to the questionnaire $\left(\mathrm{M}_{\mathrm{age}}=20.96\right)$, of whom $81.4 \%$ were women, and only $18.6 \%$ were men. The gender bias in the distribution of students is the usual one, and it characterizes studies previously carried out with students taking education degrees, which have a predominantly female population [43] (Table 1). Regarding the degree course undertaken, $41.7 \%$ of students belonged to Primary Ed $(\mathrm{N}=65), 39.1 \%$ to Early Childhood Ed ( $\mathrm{N}=61)$, and $19.2 \%$ to Social $\mathrm{Ed}(\mathrm{N}=30)$.

Table 1. Sample characteristics.

\begin{tabular}{cccccc}
\hline Grade & N & Male & Female & M $_{\text {age }}$ & Number of Work Groups \\
\hline Primary Education & 65 & 21 & 44 & 20.17 & 19 \\
Early Childhood Education & 61 & 7 & 54 & 20.93 & 20 \\
Social Education & 30 & 1 & 29 & 22.70 & 12 \\
Total & 156 & $29^{1}$ & 127 & 20.96 & 51 \\
\hline
\end{tabular}

\footnotetext{
${ }^{1}$ Gender Bias.
} 


\section{Analysis of Data and Results}

The results are presented according to three categories of analysis. First, we give the descriptive analysis of the identification variables, as well as the other items from the questionnaire and the dimensions that group them. In said descriptive analysis, the means and standard deviations of the dimensions under study are used, along with the most representative items from the dimensions. The investigation of relationships between variables and significant differences between groups was carried out through correlational and causal analysis, using Pearson's r. Second, we present the correlational analysis, and, lastly, we study the statistical differences in order to establish possible relationships between the variables. The effect of the type of methodology used in the different dimensions was analyzed by means of a mixed variance analysis (ANOVA) using degree course as the between-groups factor, and dimension scores in the different methodologies as the repeated measures factor. For the in-depth analysis of differences, Bonferroni post hoc was performed. To analyze the data, SPSS version 26 and Jasp 0.14.1 statistical packages were used.

In order to later analyze possible relationships, we asked students if they had previously used these methodologies. In respect of DT, $70.5 \%(\mathrm{~N}=110)$ of students said that they had never used it, and only $9 \%(\mathrm{~N}=14)$ said that they had used it more than once. Regarding social networks, $53.2 \%(\mathrm{~N}=83)$ had never used them in an educational context, and $10.9 \%(\mathrm{~N}=17)$ claimed to have used them in several subjects.

When students were asked whether the development of practices seemed easier with the use of these methodologies, on a scale from 1 ("much easier") to 10 ("much more difficult"), a central tendency was observed $(\mathrm{M}=5.2$; $\mathrm{SD}=2.63)$. Only $5.1 \%$ gave the response "much more difficult" and 11.5\% answered "much easier".

When asked to what extent they considered the effort made to be worth the learning achieved through these methodologies, $92.3 \%$ of the students responded "a lot". In addition, $91.7 \%$ of the students affirmed that the effect of Design Thinking would not be the same without the use of social networks.

For the general analysis of the dimensions, the mean scores were analyzed.

In the dimension for "motivation" generated by DT, it was $(\mathrm{M}=3.72 ; \mathrm{SD}=0.89)$, and for motivation generated by social networks, it was $(M=3.76$; $S D=0.92)$. Specifically, analyzing the item that inquired to what extent students believed that DT had increased their motivation relating to practices, $22.27 \%$ responded that it had increased it "quite a $\operatorname{lot}^{\prime}$, $18.36 \%$ responded "a lot", and $12.89 \%$ responded "greatly"; only $12.17 \%$, on the other hand, answered "a little" or "very little". Meanwhile, when asked in the same item about the influence of social networks, $16.8 \%$ answered "quite a lot", $21.09 \%$ answered "a lot", and $16.40 \%$ answered "greatly". Here, 10.89\% responded "a little", "very little", or "not at all".

In the dimension for "involvement" in practices, we observed that for both DT and social networks, the students' scores gave $\mathrm{M}>3.8\left(\mathrm{M}_{\mathrm{DT}}=3.86 ; \mathrm{SD}_{\mathrm{DT}}=0.75\right.$ and $\mathrm{M}_{\mathrm{SN}}=3.81$; $\mathrm{SD}_{\mathrm{SN}}=0.77$ ). Among the items relevant to this dimension, the item "to what extent has the use of these strategies led you to be more involved in group work?" was the one that presented the most remarkable results. For both strategies, $\mathrm{M}>4\left(\mathrm{M}_{\mathrm{DT}}=4.19 ; \mathrm{SD}_{\mathrm{DT}}=0.85\right.$ and $\mathrm{M}_{\mathrm{SN}}=4.17 ; \mathrm{SD}_{\mathrm{SN}}=0.87$ ). Regarding the item in which the lowest scores were obtained, the two strategies differ. In the case of DT, it was the item, "to what extent has it led you participate more in class?" $(\mathrm{M}=3.55$; $\mathrm{SD}=1.10)$, whereas for social networks, it was, "to what extent has it led you to work in an autonomous way?" $(\mathrm{M}=3.55 ; \mathrm{SD}=1.16)$.

In the "creativity" dimension, both methodologies were observed to score above $3.9\left(\mathrm{M}_{\mathrm{DT}}=3.92 ; \mathrm{SD}_{\mathrm{DT}}=0.78\right.$ and $\left.\mathrm{M}_{\mathrm{SN}}=3.94 ; \mathrm{SD}_{\mathrm{SN}}=0.80\right)$, and, for both, the highest scoring item was "has made you want to do something different from the rest and be original" $\left(\mathrm{M}_{\mathrm{DT}}=4.19 ; \mathrm{SD}_{\mathrm{DT}}=0.9\right.$ and $\left.\mathrm{M}_{\mathrm{SN}}=4.24 ; \mathrm{SD}_{\mathrm{SN}}=0.9\right)$. Analyzing the responses in percentages, more than $70 \%$ of participants stated that both methodologies had influenced them "a lot" or "greatly" in wanting to do something different; specifically, $74.99 \%$ for social networks and $73.71 \%$ for DT. 
In the "communication" dimension, the methodology based on social networks scored higher than that based on DT $\left(\mathrm{M}_{\mathrm{DT}}=3.81 ; \mathrm{SD}_{\mathrm{DT}}=0.86\right.$ and $\left.\mathrm{M}_{\mathrm{SN}}=3.93 ; \mathrm{SD}_{\mathrm{SN}}=0.83\right)$. The item "has fostered close working with your teacher" had the highest scores for both methodologies $\left(\mathrm{M}_{\mathrm{DT}}=4.00 ; \mathrm{SD}_{\mathrm{DT}}=0.97\right.$ and $\left.\mathrm{M}_{\mathrm{SN}}=4.09 ; \mathrm{SD}_{\mathrm{SN}}=0.99\right)$. In the percentage analysis, $73.06 \%$ stated that social networks had fostered close working with the teacher "a lot" or "greatly". Similarly, $69.87 \%$ stated that DT had fostered it "a lot" or "greatly".

Analyzing the data in the "monitoring" dimension, it was found that both methodologies scored above $4\left(\mathrm{M}_{\mathrm{DT}}=4.05 ; \mathrm{SD}_{\mathrm{DT}}=0.85\right.$ and $\left.\mathrm{M}_{\mathrm{SN}}=4.16 ; \mathrm{SD}_{\mathrm{SN}}=0.84\right)$. In the "dissemination" dimension, the SN methodology scored higher than that of DT $\left(\mathrm{M}_{\mathrm{DT}}=4.05\right.$; $\mathrm{SD}_{\mathrm{DT}}=0.85$ and $\left.\mathrm{M}_{\mathrm{SN}}=4.16 ; \mathrm{SD}_{\mathrm{SN}}=0.84\right)$.

In the "success" dimension, both methodologies scored $\mathrm{M}>4\left(\mathrm{M}_{\mathrm{DT}}=4.09 ; \mathrm{SD}_{\mathrm{DT}}=0.86\right.$ and $\left.\mathrm{M}_{\mathrm{SN}}=4.14 ; \mathrm{SD}_{\mathrm{SN}}=0.87\right)$. Such was not the case in the "social involvement" dimension, in which neither of the two methodologies exceeded $3.8\left(\mathrm{M}_{\mathrm{DT}}=3.73 ; \mathrm{SD}_{\mathrm{DT}}=0.98\right.$ and $\mathrm{M}_{\mathrm{SN}}=3.76 ; \mathrm{SD}_{\mathrm{SN}}=0.69$ ).

As may be observed in Table 2, all of the dimensions analyzed showed positive and significant correlations (99\% confidence level) with the item "to what extent do you consider that the learning you have achieved through these methodologies is worth the effort made, as opposed to what you might achieve using a traditional methodology?". By contrast, there was no significant correlation between the dimensions and the variable "has the development of your practices seemed easier than practices that are carried out in the usual way, without using these methodologies?".

Table 2. Results of correlations between the study dimensions and variables related to the ease of development of practices and whether the effort made was worth it.

\begin{tabular}{|c|c|c|c|}
\hline & & $\begin{array}{c}\text { Ease in the Development } \\
\text { of Practices }\end{array}$ & $\begin{array}{l}\text { The Effort Made } \\
\text { Was Worth It }\end{array}$ \\
\hline \multirow{2}{*}{ Motivation DT } & Pearson correlation & -0.091 & $0.501 * *$ \\
\hline & Sig. (bilateral) & 0.256 & 0.000 \\
\hline \multirow{2}{*}{ Motivation SN } & Pearson correlation & -0.003 & $0.350 * *$ \\
\hline & Sig. (bilateral) & 0.969 & 0.000 \\
\hline \multirow{2}{*}{ Involvement DT } & Pearson correlation & -0.053 & $0.464^{* *}$ \\
\hline & Sig. (bilateral) & 0.514 & 0.000 \\
\hline \multirow{2}{*}{ Involvement SN } & Pearson correlation & -0.032 & $0.440 * *$ \\
\hline & Sig. (bilateral) & 0.693 & 0.000 \\
\hline \multirow{2}{*}{ Creativity DT } & Pearson correlation & -0.072 & $0.352 * *$ \\
\hline & Sig. (bilateral) & 0.374 & 0.000 \\
\hline \multirow{2}{*}{ Creativity SN } & Pearson correlation & -0.036 & $0.346^{* *}$ \\
\hline & Sig. (bilateral) & 0.652 & 0.000 \\
\hline \multirow[b]{2}{*}{ Communication DT } & Pearson correlation & -0.097 & $0.425^{* *}$ \\
\hline & Sig. (bilateral) & 0.230 & 0.000 \\
\hline \multirow[b]{2}{*}{ Communication SN } & Pearson correlation & -0.082 & $0.410^{* *}$ \\
\hline & Sig. (bilateral) & 0.306 & 0.000 \\
\hline \multirow{2}{*}{ Monitoring DT } & Pearson correlation & -0.045 & $0.458^{* *}$ \\
\hline & Sig. (bilateral) & 0.576 & 0.000 \\
\hline \multirow{2}{*}{ Monitoring SN } & Pearson correlation & -0.058 & $0.470 * *$ \\
\hline & Sig. (bilateral) & 0.471 & 0.000 \\
\hline \multirow{2}{*}{ Dissemination DT } & Pearson correlation & -0.038 & $0.371^{* *}$ \\
\hline & Sig. (bilateral) & 0.637 & 0.000 \\
\hline \multirow{2}{*}{ Dissemination SN } & Pearson correlation & -0.048 & $0.261^{* *}$ \\
\hline & Sig. (bilateral) & 0.552 & 0.001 \\
\hline
\end{tabular}


Table 2. Cont.

\begin{tabular}{cccc}
\hline & & $\begin{array}{c}\text { Ease in the Development } \\
\text { of Practices }\end{array}$ & $\begin{array}{c}\text { The Effort Made } \\
\text { Was Worth It }\end{array}$ \\
\hline \multirow{2}{*}{ Success DT } & Pearson correlation & -0.105 & $0.476^{* *}$ \\
& Sig. (bilateral) & 0.191 & 0.000 \\
\hline \multirow{2}{*}{ Success SN } & Pearson correlation & -0.045 & $0.447^{* *}$ \\
& Sig. (bilateral) & 0.581 & 0.000 \\
\hline \multirow{2}{*}{ Social involvement DT } & Pearson correlation & 0.004 & $0.394^{* *}$ \\
& Sig. (bilateral) & 0.963 & 0.000 \\
\hline \multirow{2}{*}{ Social involvement SN } & Pearson correlation & 0.005 & $0.382^{* *}$ \\
& Sig. (bilateral) & 0.948 & 0.000 \\
\hline
\end{tabular}

** The correlation is significant at the 0.01 level (bilateral).

In addition, there are significant and positive correlations between the dimensions studied. They all obtain Pearson correlation values greater than 0.4, with $99 \%$ confidence levels $(p<0.01)$. Herein, what is interesting is not only the relationship between aspects such as motivation and communication, but also the existence of a correlation between the scoring of these variables with respect to the use of social networks and Design Thinking methodology.

The repeated measures ANOVA showed that, in the "communication" dimension, there were significant differences according to the methodology $(F(1153)=8.443$, Mse $=0.53$, $p<0.01)$. In the analysis of the interaction, significant differences were also observed $(F(2153)=4.689$, Mse $=0.29, p<0.01)$.

Given that the interaction between the two variables was significant, a decomposition was carried out. First, the simple effects for the scores in both methodologies were analyzed, and it was found that there were significant differences between student groups in the scores given to DT $(p<0.01)$, while no differences existed in those given to social networks. Subsequently, a Bonferroni post hoc analysis was performed to further investigate these differences, and it was found that the Early Childhood Ed group of students differed from the Social Ed group $(p=0.03)$.

Analyzing the simple effect for groups, it was observed that the Social Ed group differed from the other groups in giving similar scores to the motivation derived from the use of DT and of social networks. Both the Early Childhood Ed group $(p<0.001)$ and the Primary Ed group $(p<0.01)$ showed significant differences regarding the two methodologies used, giving higher scores to social networks in both groups.

In the "motivation" dimension, the repeated measures ANOVA showed that there was no main effect for the methodology $(F(1153)=0.13$, Mse $=0.04, p=0.72)$. Nonetheless, differences were observed in the interaction with the degree course $(F(2153)=3.14$, Mse $=0.96, p<0.05$ ).

The decomposition of the interaction showed that there were significant differences between groups in the scores awarded to DT $(p<0.001)$, with no differences for social networks. In a further examination of those differences, the Bonferroni post hoc showed that the Early Childhood Ed group differed both from the Primary Ed group $(p=0.04)$, and the Social Ed group $(p=0.01)$.

Analyzing the simple effect for groups, significant differences were observed in the scores given to DT and social networks exclusively in the Early Childhood Ed group $(p=0.2)$.

The repeated measures ANOVA showed that there was a main effect for methodology in the "monitoring" dimension $(F(1153)=5.87$, Mse $=0.59, p=0.01)$. No differences were observed in the interaction with degree course.

Nevertheless, significant differences were observed between the degree courses $(F(2153)=3.36$, Mse $=4.36, p=0.03)$. 
Analysis of the simple effects showed that there were significant differences between the two methodologies for the Early Childhood Ed $(p=0.005)$ and Primary Ed $(p=0.05)$ groups, with no differences for the Social Ed group.

There was a main effect for methodology in the "dissemination" dimension $(F(1153)=20.256$, $M s e=3.71, p<0.001)$. No differences were observed in the interaction with degree course. In addition, significant differences were observed between groups $(F(2153)=5.098$, Mse $=6.50$, $p=0.007)$.

The analysis of the simple effects, using Bonferroni, showed that there were differences between the Early Childhood Ed and Social Ed groups $(p=0.01)$ and differences close to significance between Early Childhood Ed and Primary Ed $(p=0.06)$.

In the "involvement in social actions" variable, there was no main effect for methodology $(p=0.6)$, nor were there significant differences in the interaction with groups $(p=0.4)$. Nonetheless, differences were once again observed between the groups $(F(2153)=5.38$, Mse $=9.11, p=0.006$ ).

The Bonferroni post hoc analysis showed that the Early Childhood Ed group differed from the Social Ed group in this variable $(p=0.004)$.

\section{Conclusions and Discussion}

Although the use of participatory methodologies is well-established in university contexts, and their effectiveness is well-documented, the DT methodology is practically unknown among the majority of university students [44,45]. Though it is a methodology originating in the business sphere, DT offers many benefits in education [18,19,22,23]; yet, more research and greater dissemination of results are required. Moreover, some of the initial reluctance toward its use is derived from the possible difficulties [46]; however, our results confirm that there is not an excessive difficulty associated with its use. This situation is similar to that concerning the use of social networks in higher education [47]; although their educational potential is recognized, as shown in the study by [43], it seems that their use as a motivating tool within university classrooms is far from being consolidated. Ultimately, the students participating in our study confirmed that the effort made in the use of these methodologies is worth the learning achieved. These results are similar to those reported by [31,33].

One of the most significant possibilities associated with the use of participatory methodologies has to do with their motivational capacity [31,48]. Both DT and social networks were shown to help students in the processes of motivation relating to practices, and also in their search for new applications and resources to develop those practices. The motivation observed is consistent with the scores analyzed for involvement. The use of these two methodologies has led students to be more involved, both in group work and in individual work $[18,36]$. It has fostered their efforts and it has generated situations in which they have had to leave their comfort zone. Nonetheless, and unsurprisingly, when asked to what extent social networks promote autonomous working, scores were significantly lower compared to Design Thinking. Social networks, almost by definition, offer a global, participatory, and social vision, seeking even among individual actions the complicity of the group for dissemination.

One of the capacities that these methodologies most enable, it would appear, is creativity. Both DT and Instagram provide a door to creativity: the possibility of generating new ideas, of offering new products - sought out through DT and disseminated via social networks. It is the latter that seem to have offered the students in our study the greater possibilities for communication.

Students positively assess communication with the teacher conducted through this communication channel [47], which has also allowed continuous monitoring of work and learning processes. Moreover, the students in our study stated that close working with the teacher was greatly nurtured through this use of social networks. Such improvement was also reflected in the monitoring dimension, which is closely related to that of communication. More specifically, improvements were seen in the teacher-student interchange and in 
the teachers' monitoring of the entire teaching-learning process, offering support, advice, and feedback. It is social networks that contributed in large part to this situation, it would seem, perhaps on account of their possibilities for the following dimension on our scale: "dissemination". These findings are in accordance with the results obtained in previous studies $[30,36,47]$.

This being said, it is important to emphasize that the students in our study affirmed that both of the methodologies had contributed to their perception that they had done a good job and that it had served a purpose.

Notwithstanding the above-mentioned benefits, neither of these methodologies seem to have had an effect on the students in regard to arousing an interest in undertaking social actions [4-6], despite them framing their projects within a social analysis of needs and the possibility of responding to those needs through their work. These results show how the use of DT and of social networks seems to promote greater development of skills relating to creativity, motivation, communication, and success in comparison with other participatory methodologies that place more emphasis on the development of social and civic competences, such as service learning [45]. Nevertheless, throughout the study, we have observed important differences between groups, and social involvement was one of the dimensions in which there were more differences between degree course groups. This outcome may be due to the specific peculiarities of students studying Social Education, a degree course which in itself puts forward a vocation oriented toward social action.

Although further research is needed on the use of these methodologies in higher education and their possibilities and effects with regard to learning, we consider one of the strengths of their use with university students to be the possibility of developing transversal skills that serve to distinguish students' future careers. In this sense, future lines of research should look into students' perception and personal achievements that DT can facilitate, with an emphasis on connecting the learning obtained using these methodologies with the development of skills and professional competences.

Finally, we recognize that gender bias could be a limitation in this study. This bias is found in education careers, so it will be present in most teacher education contexts [42].

We cannot forget the importance of promoting the comprehensive training of future teachers. We have to encourage greater commitment among these teachers of the future, such that, tomorrow, they educate for change, in the interest of sustainable education.

Author Contributions: Conceptualization, E.M.D.-P. and J.M.O.-T.; methodology and formal analysis, J.M.O.-T. and M.L.-V.; investigation and writing-review and editing, E.M.D.-P., J.M.O.-T., M.L.-V. and Á.M.C.-E. All authors have read and agreed to the published version of the manuscript.

Funding: This research was funded by Instituto de Estudios Giennenses, EBM/IEG 2019.

Institutional Review Board Statement: The study was conducted according to the guidelines of the Declaration of Helsinki, and approved by the Institutional Review Board (or Ethics Committee) of University of Jaén.

Informed Consent Statement: Informed consent was obtained from all subjects involved in the study.

Data Availability Statement: Not applicable.

Conflicts of Interest: The authors declare no conflict of interest. The funders had no role in the design of the study; in the collection, analyses, or interpretation of data; in the writing of the manuscript; or in the decision to publish the results.

\section{References}

1. European University Association. COVID-19 and Universities. Available online: https://www.eua.eu/issues/27:covid-19-anduniversities-in-europe.html (accessed on 30 August 2021).

2. Aristovnik, A.; Keržič, D.; Ravšelj, D.; Tomaževič, N.; Umek, L. Impacts of the COVID-19 Pandemic on Life of Higher Education Students: A Global Perspective. Sustainability 2020, 12, 8438. [CrossRef]

3. Karalis, T.; Raikou, N. Teaching at the Times of COVID-19: Inferences and Implications for Higher Education Pedagogy. Int. J. Acad. Res. Bus. Soc. Sci. 2020, 10, 479-493. [CrossRef] 
4. Esteban, F.; Martínez, M. ¿Son universidades todas las universidades? La universidad como comunidad ética. Bordón 2012, 64, 77-92.

5. Naval, C.; García, R.; Puig, J.; Anxo, M. La formación ético-cívica y el compromiso social de los estudiantes universitarios. Encount. Educ. 2011, 12, 77-91. [CrossRef]

6. Ortega-Tudela, J.M.; Cámara-Estrella, A.M.; Díaz-Pareja, E.M. Service learning as a tool to enhance future teachers' media competence/Aprendizaje-Servicio como estrategia favorecedora del desarrollo de la competencia mediática en futuros docentes. Cult. Educ. 2015, 27, 440-455. [CrossRef]

7. Soto-González, M.D.; Rodrigo-Segura, F.J. El Aprendizaje-Servicio una oportunidad para atender la diversidad en los títulos del Grado de Maestro/a de Educación Infantil y Primaria de Florida Universitària. In Contextos per a la Inclusió en la Societat del Coneixement. Congrés D'Educació Inclusiva; Villaescusa, M.I., Ed.; Generalitat Valenciana: Valencia, Spain, 2016; pp. 163-166.

8. Battistoni, R.M. Service learning in political science: An introduction. Political Sci. Politics 2000, 33, 614-616. [CrossRef]

9. Urroz-Osés, A. Diseño y desarrollo: La innovación responsable mediante el Design Thinking. Ensayos 2018, 69, 195-206. [CrossRef]

10. Marcelo, C.; Rijo, D. Aprendizaje autorregulado de estudiantes universitarios: Los usos de las tecnologías digitales. Rev. Caribeña Investig. Educ. 2019, 3, 62-81. [CrossRef]

11. Scheer, A.; Noweski, C.; Meinel, C. Transforming Constructivist Learning into Action: Design Thinking in education. Des. Technol. Educ. Int. J. 2012, 17, 8-19.

12. Steinbeck, R. El «design thinking» como estrategia de creatividad en la distancia. Comunicar 2011, XIX, 27-35. [CrossRef]

13. Castillo-Vergara, M.; Álvarez-Marín, A.; Cabana-Villca, R. Design thinking: Cómo guiar a estudiantes, emprendedores y empresarios en su aplicación. Ing. Ind. 2014, 35, 301-311.

14. Brown, T. Design thinking. Harv. Bus. Rev. 2008, 86, 84-92. [PubMed]

15. Brown, T. Change by Design: How Design Thinking Transforms Organizations and Inspires Innovation; Harper Business: New York, NY, USA, 2009.

16. Hernández-Gil, C.; Núñez-López, J.A. Design thinking aplicado al mejoramiento de las competencias ciudadanas en universitarios: Voto popular. Rev. Investig. Desarro. Innov. 2020, 11, 85-98. [CrossRef]

17. Bongiovanni, I.; Balgabekova, D. Ask me if I am Engaged: A Design-led Approach to Collect Student Feedback on their University Experience. Des. Technol. Educ. Int. J. 2021, 26, 89-117. Available online: https://ojs.lboro.ac.uk/DATE/article/view/2864 (accessed on 31 August 2021).

18. Hong, S.; Kwek, D. Innovation in the Classroom: Design Thinking for 21st Century Learning. Stanford EDU. 2011. Available online: http:/ / www.stanford.edu/group/redlab/cgi-bin/materials/Kwek-Innovation\%20In\%20The\%20Classroom.pdf (accessed on 31 August 2021).

19. Anderson, N. Design Thinking: Employing an Effective Multidisciplinary Pedagogical Framework to Foster Creativity and Innovation in Rural and Remote Education. Aust. Int. J. Rural Educ. 2012, 22, 43-52.

20. Skaggs, P.; Fry, R.; Howell, B. Innovations Unlimited: Thinking About Design Thinking. Presented at the NCIIA 13th Annual Meeting, Washington, DC, USA, 13 January 2009.

21. Lee, D.; Yoon, J.; Kang, S.J. The introduction of design thinking to science education and exploration of its characterizations as a method for group creativity education. J. Korean Assoc. Sci. Educ. 2014, 34, 93-105. [CrossRef]

22. Caruso, C. The Tools of Engagement: Bridging Design Thinking and Social Media to Enhance and Support Collaborative Learning; Carleton University: Ottawa, ON, Canada, 2011.

23. Bruton, A. Teaching and Learning for the 21st Century. In Proceedings of the International Council for Small Business: International Conference, Cincinnati, OH, USA, 24-27 June 2010.

24. Carrol, M.P. Shoot for The Moon! The Mentors and the Middle Schoolers Explore the Intersection of Design Thinking and STEM. J. Pre-Coll. Eng. Educ. Res. 2014, 4, 3. [CrossRef]

25. Lindberg, T.; Noweski, C.; Meinel, C. Evolving discourses on design thinking: How design cognition inspires meta-disciplinary creative. Technoetic Arts A J. Specul. Res. 2010, 8, 31-37. [CrossRef]

26. Barragán, R. El uso de las Redes Sociales Digitales en la educación reglada. Una experiencia de orientación académico profesional con alumnado de Bachillerato. In Tecnología, Innovación e Investigación en los Procesos de Enseñanza-Aprendizaje; Roig-Vila, R., Ed.; Octaedro: Barcelona, Spain, 2016; pp. 88-95.

27. Pérez, A. Redes sociales y educación. Una reflexión acerca de su uso didáctico y creativo. Rev. Creat. Soc. 2013, $21,1-23$.

28. Fazi, R.; El Afia, A.; Chiheb, R. Exploring the Potential Benefits of Using Social Media in Education. Int. J. Eng. Pedagog. 2013, 3, 50-53. [CrossRef]

29. Habes, M.; Salloum, S.A.; Alghizzawi, M.; Alshibly, M.S. The role of modern media technology in improving collaborative learning of students in Jordanian universities. Int. J. Inf. Technol. Lang. Stud. 2018, 2, 71-82.

30. Gómez-Hurtado, I.; García Prieto, F.J.; Delgado-García, M. Uso de la red social Facebook como herramienta de aprendizaje en estudiantes universitarios: Estudio integrado sobre percepciones. Perspect. Educ. 2018, 57, 99-119. [CrossRef]

31. Gómez, M.; Roses, S.; Farias, P. El uso académico de las redes sociales en universitarios. Comunicar 2012, 38, 131-138. [CrossRef]

32. Ranieri, M.; Rosa, A.; Manca, S. Unlocking the potential of social media for participation, content creation and e-engagement: Students' perspectives and empowerment. In E-Learning and Social Media: Education and Citizenship for the Digital 21st Century; Information Age Publishing: Scottsdale, AZ, USA, 2016; pp. 223-248. 
33. Xie, W. Social network site use, mobile personal talk and social capital among teenagers. Comput. Hum. Behav. 2014, 41, 228-235. [CrossRef]

34. Greenhow, C.; Lewin, C. Social media and education: Reconceptualizing the boundaries of formal and informal learning. Learn. Media Technol. 2016, 41, 6-30. [CrossRef]

35. Awais Gulzar, M.; Ahmad, M.; Hassan, M.; Imran Rasheed, M. How social media use is related to student engagement and creativity: Investigating through the lens of intrinsic motivation. Behav. Inf. Technol. 2021. [CrossRef]

36. Muñoz-Prieto, M.M.; Fragueiro-Barreiro, M.S.; Ayuso-Manso, M.J. La importancia de las redes sociales en el ámbito educativo. Esc. Abierta 2013, 16, 91-104.

37. García-Ruiz, R.; Tirado, R.; Hernando, A. Redes sociales y estudiantes: Motivos de uso y gratificaciones. Evidencias para el aprendizaje. Aula Abierta 2018, 47, 291-298. [CrossRef]

38. Gavaldón, G.; Calderón, A. Repensar la formación docente: Pedagogía inclusiva apoyada en las TIC. In Formación y Transformación para la Educación Inclusiva en la Universidad. Actas del I Congreso Internacional Virtual de Educación Inclusiva en la Universidad; García, P.J., Pinagorte, M., Véliz, V., De la Herrán, A., Montiano, B., Eds.; Editorial Universidad de Granada: Granada, Spain, 2017; pp. 383-394.

39. UNESCO. Directrices para las Políticas de Aprendizaje Móvil. Francia: Organización de las Naciones Unidas para la Educación, la Cultura y las Ciencias. 2013; p. 31. Available online: https://eduonline.ibero.mx/DEDsitio/src/Aprendizaje_movil.pdf (accessed on 31 August 2021).

40. Díaz-Pareja, E.M.; Cámara-Estrella, A.M.; Muñoz-Galiano, I.M.; Ortega-Tudela, J.M. Group work: Prospective teachers' acquisition of transversal competences. Educ. Stud. 2018, 44, 45-56. [CrossRef]

41. Ayre, C.; Scally, A.J. Critical values for Lawshe's content validity ratio: Revisiting the original methods of calculation. Meas. Eval. Couns. Dev. 2014, 47, 79-86. [CrossRef]

42. Gialamas, V.; Nikolopouiou, K.; Kutromanos, G. Student teachers' perceptions about the impact of Internet usage on their learning and jobs. Comput. Educ. 2013, 62, 1-7. [CrossRef]

43. González, J.; Lleixà, M.; Espuny, C. Las redes sociales y la educación superior: Las actitudes de los estudiantes universitarios hacia el uso educativo de las redes sociales, de nuevo a examen. Educ. Knowl. Soc. EKS 2016, 17, 21-53. [CrossRef]

44. Cámara-Estrella, A.M.; Díaz-Pareja, E.M.; Ortega-Tudela, J.M. Aprendizaje-Servicio en la universidad: Ayudando a la escuela a atender a la diversidad a través de las TIC. Bordón Rev. Pedagog. 2017, 69, 73-87. [CrossRef]

45. Lor, R. Design thinking in Education: A Critical Review of Literature. In Proceedings of the 3rd International Academic Conference on Social Sciences and Management, Bangkok, Thailand, 24-26 May 2017.

46. Al-Rahmi, W.M.; Othman, M.S.; Musa, M.A. The improvement of students' academic performance by using social media through collaborative learning in Malaysian higher education. Asian Soc. Sci. 2014, 10, 210.

47. Kröper, M.; Fay, D.; Lindberg, T.; Meinel, C. Interrelations between motivation, creativity and emotions in Design thinking processes-An empirical study bsed on regulatory focus theory. In Proceedings of the 1st International Conference on Design Creativity ICDC 2010, Kobe, Japan, 29 November-1 December 2010.

48. Grammenos, D.; Antona, M. Future designers: Introducing creativity, design thinking \& design to children. Int. J. Child-Comput. Interact. 2018, 16, 16-24. [CrossRef] 